\title{
Robert M. Oneal and Lauralee A. Lutz: Leaders in Plastic Surgery (The Dingman-Grabb Era 1946-1986)
}

\author{
Joseph Gryskiewicz ${ }^{1}$ (D)
}

Received: 23 October 2017 / Accepted: 28 October 2017/Published online: 7 December 2017

(C) Springer Science+Business Media, LLC, part of Springer Nature and International Society of Aesthetic Plastic Surgery 2017

Reed O. Dingman and William C. Grabb were inspirational giants, but this book is much more than simply about them as leaders. We are treated to rare insights into our young specialty and the seminal politics which allowed a new plastic surgery "section" to flourish. The book is a microcosm of our national and international development. The growth and maturation of the Michigan program have paralleled the development of our entire specialty of plastic surgery. Recognizing these parallels, feeling the excitement as our infant specialty of plastic surgery matured, and understanding the implications of these developments on the future of our specialty are important for our history and future growth both at home and abroad. The authors have given us an expertly crafted book. It brought back so many memories from my brief time there as a medical student...all the personalities and of course Drs. Dingman and
Grabb. I still have the beautiful notes they wrote to me on the inside cover of my own copy of Grabb and Smith. They were so encouraging!

This book is a gift from generation to generation celebrating the remarkable history of plastic surgery at the University of Michigan. The authors have brought to life the extensive accomplishments of these two leaders in terms of surgical techniques, surgical education, and important applied research. Significant developments have been expertly documented and creatively framed to develop an interesting story. Personal memories, anecdotes, nostalgic photos, and stories have been sprinkled throughout. I believe anyone interested in the history of medicine and the development of our plastic surgery specialty will find this an engaging and captivating read.

Joseph Gryskiewicz

drjoe@tcplasticsurgery.com

1 Twin Cities Cosmetic Surgery, Burnsville, MN, USA 